\title{
Vocational Business Students' Conceptions and Misconceptions of Taxes as an Input for Instruction and Curriculum Development
}

\author{
Nora Cechovsky* \\ Vienna University of Economics and Business, Institute for Business Education, \\ Welthandelsplatz 1, 1020 Vienna, Austria
}

Received: 06.08.2019, Accepted: 08.01.2020, Published: 10.07.2020

\begin{abstract}
Context: Tax evasion and tax compliance are important topics on a European level. Next to regulations and fines, the understanding of tax-related issues impacts a tax compliance decision. Vocational business students already pay taxes and are potential future entrepreneurs who will increasingly have to deal with tax-related issues in the future. Tax-related content is, therefore, integrated in the curriculum of business colleges in Austria. Information on business students' conceptions and misconceptions concerning taxes can serve as valuable input for instruction and curriculum development.
\end{abstract}

Approach: In order to explore the conceptions and misconceptions of taxes among potential future entrepreneurs, students aged between 17 and 18 from business colleges in Austria were interviewed. Therefore, the technique of problem-centred interviews was chosen. The material was then analysed by using Mayring's content analytic method of structuring.

Findings: The students' conceptions and misconceptions of taxes, the difference to scientific knowledge as well as possible reasons for the misconceptions are analysed and discussed. The results show that misconceptions concerning basic principles of taxes exist, that students only have vague conceptions and little experience when it comes to income tax. They do not perceive themselves as taxpayers even though many of them have work experience and they regularly act as consumers and pay value added tax. Even though the students are

*Corresponding author: Nora.cechovsky@wu.ac.at 
more familiar with value added tax rates, misconceptions concerning the reasons behind the differences in rates exist. Finally, most of the students only fragmentally remember the last fundamental tax reform in Austria.

Conclusion: The findings as well as an analysis of the curriculum suggest that the students are missing basic knowledge on taxes as for example the difference between fees and taxes. On a curricular level, knowledge important for the individual taxpayer should build the ground for further business-related content. Finally, background knowledge on why different forms of taxes exist and on tax reforms should foster a deeper understanding and complement the factual knowledge most students already possess.

Keywords: Vocational Business Students' Conceptions, Vocational Business Students' Misconceptions, Tax Literacy, Tax Education, Tax Knowledge, Vocational Education and Training, VET

\section{Introduction}

Tax avoidance and tax evasion have a negative impact on the entire European Union since they result in a decrease in tax intakes of the member states (Vella, 2015). Therefore, the European Commission proposes a variety of regulations to reduce the amount of funds lost (European Commission, 2017a, p. 4), one being an Anti-Tax Avoidance Directive targeted to enhance tax compliance (European Commission, 2016a). Next to regulations and fines tax payer education is an important instrument to promote tax compliance (Organisation for Economic Co-Operation and Development [OECD] \& The International and Ibero-American Foundation for Administration and Public Policies, 2015). Hence, not being aware of tax regulations can lead to involuntary tax evasion and, consequently, to lost funds for the society but also to fines for individuals (Kirchler et al., 2008). Furthermore, not understanding the societal importance of taxes can lead to non-compliance as well. Recent studies find that uncertainty concerning taxation issues among entrepreneurs constitutes a problem across the European Union (European Commission, 2017c).

In the countries of the European Union, however, only little research on tax literacy and tax compliance as well as on how to improve the understanding of students in the field of taxation has been done. A low level of tax literacy among several target groups was found by empirical studies in Malaysia, India and Australia (Bhushan \& Medury, 2013; Chardon et al., 2016; Latiff et al., 2005). Furthermore, studies conducted in Norway, Germany and Hong Kong, employing an experimental design, found that an increase in tax knowledge leads to a more positive attitude towards taxes (Djawadi \& Fahr, 2013; Eriksen \& Fallan, 1999; Wong \& Lo, 2015). Additionally, several cross-sectional studies carried out in Malaysia, Australia, Pakistan, Nigeria and Austria found significant relationships between tax knowledge and tax 
compliance (Cechovsky, 2018a; Kirchler et al., 2006; Gangl et al., 2014; Oladipupo \& Obazee, 2016; Palil et al., 2013). A rather low number of studies used interviews in order to further explore the tax knowledge of individuals including a study from Great Britain (Furnham, 2005). Based on this research gap, the goal of this study is to present young people's conceptions and misconceptions of tax-related issues explored through problem-centred interviews which can then be used as an input for instruction in the field of taxation. The target group of this study are students from the fourth grade of business colleges in Austria. Business colleges in Austria can be described as five-year full-time upper secondary schools which lead to a university entry qualification and provide a business-related vocational education (Markowitsch \& Hefler, 2018). One focus of the curriculum is entrepreneurship education. Therefore, the students learn how to develop a business plan and are taught several business-related subjects such as for example business administration, accounting, training firm (a model enterprise for training business related competences which is run by the students) or economics. In detail, the students should already have developed several tax-related competences as for example dealing with value added tax in accounting, filing tax returns and employee assessments (Bundesministerium für Bildung, 2014).

An analysis of the curriculum of business colleges in Austria shows that at the time the interviews were held, the students already had been taught tax-related content in the subjects accounting and business administration. In the first two grades six tax-related competences are taught in the subject accounting relating to value-added tax, the determination of the taxable income, personnel accounting and employee assessment. In the first semester of the fourth grade tax law is taught with regard to the difference to company law. Furthermore, in the first year of the subject business administration more general economic competences are taught such as the economic interrelations between actors of the economy which can build the basis for an understanding of taxes. Additionally, different contracts of employments are taught also from a tax perspective. All in all, the target group of this study has already gained a some understanding of tax-related issues (Cechovsky, 2018a, pp. 101-106). Therefore, the results of this study are of interest for teachers and school representatives, since they explicate the prior understanding for the focus on taxation which is integrated in the curriculum in the subject accounting in the end of the fourth grade.

In this paper first of all, insights into research from the fields of tax literacy and students' conceptions and misconceptions are presented. Then, the research questions are outlined, the methods applied in this study are presented and the sample is described. Subsequently, the results are presented, starting with the students' general associations concerning taxes, continuing with the students' conceptions and misconceptions on income tax and value added tax and finally focusing on students' conceptions and misconceptions of a recent tax reform. The results then serve as a base for recommendations for tax education at business colleges in Austria, which are presented in the final section. 


\section{Tax Literacy}

Hofmann et al. (2008) compile a comprehensive review on the conditions of voluntary tax compliance. They focus on factors such as knowledge, attitudes, social norms, perceptions of fairness and motivational postures, which are considered relevant internal factors for tax compliance. In various studies the researchers discover that many people have a lack of knowledge concerning tax law, basic concepts of taxation and tax rates, all of them leading to an unfavourable attitude towards taxes (Hofmann et al., 2008, p. 2). Knowledge gained through personal experience and positive attitudes are seen as prerequisites for behavioural intentions (Ajzen, 1991), and consequently increase trust in the government and lead to tax compliance (Hofmann et al., 2008, p. 3). Several studies investigate the influence of social norms on tax compliance behaviour in various countries (Hofmann et al., 2008, p. 4).

In addition, a high perception of fairness seems to have also a positive effect on tax compliance (Hofmann et al., 2008, p. 5). The literature review suggests that internal variables are important for the tax payers' willingness to coorporate (Hofmann et al., 2008, p. 7) and confirms Kamleitner et al's (2012) review on the tax compliance of small business owners. The latter's goal is to develop a framework of factors influencing tax compliance (Kamleitner et al., 2012, p. 330). They seem to rely on a rather broad definition of small businesses (Kamleitner et al., 2012, pp. 331-332). It includes various forms of businesses that are centred around one single individual and decision-maker.

Researchers who adopt a psychological approach find three main characteristics that constitute the tax situation of small business owners (Kamleitner et al., 2012, pp. 334-340). Firstly, small business owners usually have a perceived opportunity of non-compliance since they do their taxes themselves. Secondly, filing the tax return requires comprehensive knowledge in order to be able to adhere to rules and regulations. Thirdly, paying taxes can be framed differently in human minds, small business owners mostly perceive paying taxes as a loss of money and as a limitation of freedom. The findings show that general knowledge as well as tax specific-knowledge impact the ability and the intention to comply with tax laws. Thus, the awareness for the necessity of taxes seems to have a positive impact on compliance. Furthermore, tax-specific knowledge is important in order to increase the ability to file a tax return and competently deal with tax-specific problems. Here, Kamleitner et al. (2012, p. 340) conclude that tax-related decisions are mainly influenced by perceptions.

Tax-related issues, however, have received fairly little attention in the research on students' conceptions (Furnham, 2005, p. 704). There is only a small amount of studies that focus on students' conceptions in the field of taxation. The methods that are applied in these studies, however, can be described as being more quantitatively oriented than focusing on the variations of students answers. Furnham (2005) for example interviewed 60 children between the age of ten and fifteen with the following questions: "(1) What does tax mean to you? (2) Who decides how much tax people have to pay? (3) What does the government spend 
our tax money on? (4) Do people in other countries pay tax?" (Furnham, 2005, p. 706). The results show that the understanding of taxation increases with age. Furnham $(2005$, p. 710$)$ concludes that a full understanding of taxation, which would include the differentiation of types of taxes, who is responsible for decisions concerning taxation and why people have to pay taxes, will probably be developed by the late teenage years. However, a similar questionnaire study by Furnham and Rawles (2004, p. 19) among 247 British students at the age of 19 shows that they still only have a basic technical understanding of taxes. The authors ascribe this to the fact that most students had not yet paid income tax (Furnham \& Rawles, 2004, p. 19).

Many studies focusing on tax literacy define tax literacy as a part of financial literacy (Cvrlje, 2015, p. 156). Financial literacy is mainly concerned with personal financial issues as for example the widely used definition by Atkinson and Messy (2012, p. 14) shows: "Financial literacy is a combination of awareness, knowledge, skill, attitude and behaviour necessary to make sound financial decisions and ultimately achieve individual financial wellbeing." This, however, would limit the content of tax knowledge to the individual tax return. Applying the research background of economic literacy to tax literacy as it is done in this study includes a broader tax knowledge. Economic literacy comprises next to content important for the individual, an understanding of macroeconomic issues (Beck, 1989; Schumann et al., 2011) and recent economic developments (Holtsch \& Eberle, 2016). Therefore, tax literacy within this study is defined in accordance with Cechovsky (2018a, p. 22) as "tax knowledge concerning the individual and society, including recent developments".

Next to knowledge also non-cognitive aspects such as interest, attitude and a tax compliance behaviour are part of the construct (Cechovsky, 2018a, p. 22). In this paper, however, the focus is on conceptions and misconceptions on an individual level and concerning a recent tax reform. The recent tax reform was included, since being aware of recent economic developments as already mentioned above, is an important part of an economic competence (Holtsch \& Eberle, 2016). Furthermore, the tax reform led to substantial changes in the Austrian tax law including for example the introduction of a new value added tax rate and received a lot of media coverage (Bundesministerium für Digitalisierung und Wirtschaftsstandort, 2015).

\section{Students' Conceptions and Misconceptions}

Knowing and using students' conceptions and misconceptions as a teacher is a part of what Shulman (1986) describes as pedagogical content knowledge. He (1986, p. 9) points out that "pedagogical content knowledge also includes an understanding of what makes the learning of specific topics easy or difficult: The conceptions and preconceptions that students of different ages and backgrounds bring with them". Also, teachers need knowledge that exceeds 
subject specific content. Therefore, research in the field of conceptions and misconceptions will continue to build the ground for effective instruction. At the same time, teachers need to develop strategies to build on conceptions and reorganise misconceptions (Shulman, 1986, p. 10).

As extensive research suggests, students' conceptions are of major importance for teaching and learning. Since the 1970s research has emphasized students' misconceptions that are inconsistent with expert knowledge (Smith III et al., 1994, p. 116). However, many articles focus on students' conceptions and misconceptions in the field of natural sciences (Eryilmaz, 2002; Nakhleh, 1992; Yates \& Marek, 2014). There is a vast variety of terms that are used in these studies: Preconceptions, alternative conceptions, naïve beliefs, alternative beliefs, alternative frameworks, informal knowledge or naïve theories (Smith III et al., 1994, p. 119).

Students' conceptions and misconceptions were explored in connection with economic topics in the recent years too. Studies include the following economic issues: The free provision of goods and services (Davies \& Lundholm, 2012), the economic crises (Aprea, 2015; Aprea \& Sappa, 2014), the price (Birke \& Seeber, 2011; Ignell et al., 2017) and economic principles (Busom et al., 2017). When analysing these studies three different research approaches become visible. While some studies focus on one approach only, other studies combine more than one of them.

The first one is based on the theoretical framework from cognitive psychology. The main interest of cognitive psychology is to uncover the biases and illusions that lead to misconceptions, which can then be actively addressed in a classroom setting in order to change the misconceptions (Marton, 2005, p. 143; Busom et al., 2017, p. 77). Based on this background Aprea (2015, p. 15), for example, analyses how and why students' conceptions of the economic crises are different from expert knowledge or official representations.

The second approach, which is also based on cognitive psychology, focuses more on the conceptual change over time by applying two or more rounds of interviews. Ignell et al. (2017, p. 69), who adopted this approach define conceptions as alternative frameworks which can be held next to scientific explanations. Busom et al. (2017, p. 77) who studied the change in economic beliefs of students in the course of a semester, for example, want to find out "how well standard economic instruction does in challenging popular misconceptions".

The third approach is based on the phenomenographic research methodology. According to Marton (2005, pp. 143-144) phenomenographic research focuses on the possible variations in conceptions, and therefore the possible ways of perceiving a phenomenon. The main goal of phenomenographic research in education is to investigate students' conceptions and misconceptions in order to find ways to change the conceptions from misconceptions to scientifically true conceptions (Marton, 2005, p. 155). This approach is for example adopted by Birke and Seeber (2011) who analyse the different understandings of economic phenomena. Furthermore, it is applied by Aprea and Sappa (2014) who identified four conceptions of 
students concerning the financial and economic crises. Within this paper, the term misconception is used for students' responses in the interviews being incorrect according to current tax law. The term conception represents the correct answer according to the tax regulations. Additionally, conceptions and misconceptions are defined as relevant prior-knowledge which serves as an input for instruction.

\section{$4 \quad$ Research Questions, Methods, Sample and Data Analysis}

Based on the research background of cognitive psychology and phenomenographic research described above, the following three research questions have been identified:

1. What different conceptions and misconceptions concerning taxes (in general, concerning income and value added tax and a recent tax reform) do students have? (phenomenography)

2. How do those misconceptions (of taxes in general, concerning income and value added tax and concerning a recent tax reform) differ from correct conceptions? (cognitive psychology)

3. What are the reasons for these misconceptions? (cognitive psychology)

In their analysis of journal publications Gurel et al. (2015) identify interviews as the most common way to learn about students' conceptions. This is no surprise since interviews are able to shed light on the cognitive structure of students. Consequently, to identify students' conceptions and misconceptions, problem-centred interviews (Witzel \& Reiter, 2012) were conducted. Lamnek (2010, p. 333) postulates that problem-centred interviews can be characterised as a method that integrates both an inductive and deductive approach. Doing that the researcher develops a theoretical prior-knowledge before conducting the interviews. Hence, the interviewer is well prepared and more aware of the research area. The goal of the problem-centred interview is to motivate the interviewee through open questions to tell her or his ideas and thoughts concerning the research topic.

Theories and hypotheses of the interviewer, however, must not influence the interviewee. In order to ensure this peer feedback was sought at several stages of the research process. Furthermore, an interview guideline was developed and used. The guideline contains, among others, the following questions:

- What do you think about when you hear the term taxes?

- What is your experiences with income tax/employee assessment? 
- What value-added tax rates exist in Austria? Why are there different rates?

- What do you remember from a recent tax reform that took place in Austria?

For this study the ethical guidelines on research published by the American Psychological Association (2017) were applied. Following these guidelines, information material on the study was developed. The regional school authorities as well as the principals and teachers were asked for their informed consent. Also, participating students (and their parents if the students were yet to attain legal age) were asked for their informed consent. Before the interview started, participants were informed about the project once more and anonymity was assured again.

Between the end of 2016 and the beginning of 2017, the author of this article conducted twenty-two interviews with students of Austrian vocational business colleges in Burgenland, Lower Austria and Vienna. Interview partners were regular students and those in talent programmes. The students were between 17 and 18 years old. The interviews length was between ten and twenty-five minutes and they were conducted in the schools' meeting rooms or in the library and the school hall, respectively. A deductive sampling strategy was applied. The goal was to increase the variance of the sample in order to gain deeper insights. The relevant categories were gender, school location (urban and rural) and talent. In detail, 13 female and 9 male students were interviewed. The sample consists of 4 students from a program for especially talented students. Furthermore, 10 students are from schools in Vienna and 12 from schools in more rural areas in Austria. All in all, six schools took part in the project. The sampling was influenced by practical issues too, since the school authorities, teachers and students had to agree to being interviewed, therefore, the sample can be described as a convenience sample. Due to the small sample, no explicit analysis according to the sampling categories was conducted.

The interviews were transcribed and analysed according to Mayring (2015). Mayring (2015, p. 67) points out that the selection of a technique should be based on the research interest. Since a prior understanding of the categories was developed before the analysis, the technique of structuring was chosen, followed by summarising as explained below. For structuring, Mayring (2015) recommends defining which parts of the text are relevant for each category. These interview parts then qualify as example for each category. Finally, coding rules are defined in order to find a clear distinction between the categories. A trial analysis helps to further refine categories. Following Mayring (2015), these categories were applied to the interviews: First associations (answer to the first interview question), employee assessment, value added tax and tax reform. Based on the categories the interviews were filtered. Subsequently, the interview parts were paraphrased and subcategories were developed. An example of the summarising process is provided in Table 1. In a first step the quotes were paraphrased and brought on an equal language level. The second step consisted of filtering 
the main meaning and generating further categories. In a final step, the new categories were outlined and overlapping generalisations were omitted.

Table 1: Example of the Interview Analysis

\begin{tabular}{|c|c|c|c|}
\hline Quote & Step 1: Paraphrase & $\begin{array}{l}\text { Step 2: } \\
\text { Generalisation }\end{array}$ & Step 3: Reduction \\
\hline $\begin{array}{l}\text { "Sales tax } 20 \% \text {, what else, } \\
\text { there is the income tax, then } \\
\text { the value added tax in the } \\
\text { commerce ..., then ... yes } \\
\text { there are a lot of other taxes } \\
\text { (Laughs)." }\end{array}$ & $\begin{array}{l}20 \% \text { sales tax, } \\
\text { value added tax, } \\
\text { many other taxes }\end{array}$ & Types of taxes & $\begin{array}{l}\text { First associations } \\
\text { concerning taxes } \\
\text { - Types of taxes } \\
\text { - Positive } \\
\text { associations } \\
\text { - Public finance }\end{array}$ \\
\hline $\begin{array}{l}\text { "According to my opinion } \\
\text { taxes are relatively useful and } \\
\text { important, because the } \\
\text { government needs certain } \\
\text { income and without taxes no } \\
\text { schools or hospitals or } \\
\text { insurance would be available. } \\
\text { A lot of positive aspects would } \\
\text { not exist." }\end{array}$ & $\begin{array}{l}\text { Taxes are useful } \\
\text { and important, } \\
\text { positive services } \\
\text { would otherwise } \\
\text { not exist } \\
\text { Taxes are used to } \\
\text { finance certain } \\
\text { public goods }\end{array}$ & $\begin{array}{l}\text { Positive associations, } \\
\text { useful } \\
\text { Public finance }\end{array}$ & \\
\hline $\begin{array}{l}\text { "Basically what you pay to the } \\
\text { government, in order to make } \\
\text { sure that we can live how we } \\
\text { live." }\end{array}$ & $\begin{array}{l}\text { Taxes are what } \\
\text { you pay in order to } \\
\text { be able to hold the } \\
\text { standards of living. }\end{array}$ & Public finance & \\
\hline
\end{tabular}

\section{$5 \quad$ Results}

In this section first associations with the term taxes are described. Thereafter, the students' conceptions and misconceptions of income tax and value added tax are presented. Finally, the conceptions and misconceptions of the students on a recent tax reform in Austria are outlined. In order to provide a comprehensive explanation, the three research questions (specified above) are answered in an integrated way. In detail, the conception or misconception is explained, followed by a description of how the misconception differs from a correct conception and an analysis of the reasons for the misconception or conception.

\subsection{Associations With Taxes}

To get a general view of the variations in students' conceptions concerning taxes, the first step was to analyse the students' initial associations with the term taxes. After informing the 
interviewee about the study as well as assuring anonymity, the interview was started with the open questions: "What do you think about when you hear the term taxes?" or "What is your first association when you hear the term taxes?". To ask open questions is a method used in phenomenographic research to uncover the relevance structure of individuals (Marton, 2005, p. 153). The results of the analysis of these first associations are shown in Table 2 below. Four different conceptions associated with taxes could be identified.

More than half of the students mention at least one type of tax during their first association (Category 1.1 in Table 2). Among the variety of tax types mentioned, the most frequent are the value added tax and the income tax, as the example quote ${ }^{1}$ in Category 1.1 in Table 2 demonstrates. Furthermore, students mention the capital gains tax, the municipal tax and the metro tax. The prominence of value added tax and income tax can be explained by the students experiences in the subject accounting where these taxes are dealt with but also by the personal relevance in the students' lives. According to Eurostat (2016) income tax and value added tax, together with social contributions, are considered the most important tax categories in Europe. For 2015 the data shows that 17.6\% of all taxes in the EU-28 are value added type taxes and $30.1 \%$ are classified as taxes on income. Taxes on capital only amount to $0.7 \%$.

One student associates the term taxes with fees that must be payed when registering a car. Fees are, however, different from taxes, since for paying fees one is entitled to a service in return, which does not apply for taxes. This misconception can be explained by the student's recent personal experience and the student is not able to differentiate between fees and taxes.

The example quote in Category 1.2 in Table 2 stands for one of the fifteen answers related to the field of public finance. This shows that most students are aware that the government uses the tax money to finance public goods. This can be explained by the everyday experience with public goods as for example schools or public transport.

Five students evaluate taxes as something important or positive during within their first reply, as the quote in Category 1.3 in Table 2 illustrates. Positive associations originate in the availability of public goods that are financed through taxes.

Five students mention that they view taxes negatively (Category 1.4 in Table 2). One student has positive as well as negative associations with the term taxes in the first question. A very negative evaluation is represented by the quote in Category 1.4 in Table 2. The negative associations are mostly justified by the large amounts of money that has to be spent on taxes.

1 Since the interviews were held in German, the interview transcripts were translated into English. 
Table 2: First Associations With Taxes

\begin{tabular}{|c|c|c|c|c|}
\hline Number & Categories & Description & Example quote & Answers \\
\hline 1.1 & $\begin{array}{l}\text { Associations } \\
\text { concerning types } \\
\text { of taxes }\end{array}$ & $\begin{array}{l}\text { Types of taxes are } \\
\text { named. }\end{array}$ & $\begin{array}{l}\text { "Sales tax } 20 \% \text {, what else, there is the } \\
\text { income tax, then the value added } \\
\text { tax in the commerce..., then ... yes } \\
\text { there are a lot of other taxes (Laughs) } \\
\text { spontaneously I do not recall so many } \\
\text { of them." }\end{array}$ & 12 \\
\hline 1.2 & $\begin{array}{l}\text { Associations } \\
\text { concerning public } \\
\text { finance }\end{array}$ & $\begin{array}{l}\text { Payments to the } \\
\text { government and } \\
\text { what is financed } \\
\text { through taxes is } \\
\text { mentioned. }\end{array}$ & $\begin{array}{l}\text { "Basically what you pay to the govern- } \\
\text { ment, in order to make sure that we } \\
\text { can live how we live." }\end{array}$ & 15 \\
\hline 1.3 & $\begin{array}{l}\text { Positive } \\
\text { associations }\end{array}$ & $\begin{array}{l}\text { Positive evaluation } \\
\text { of the tax system } \\
\text { or parts of it is } \\
\text { given. }\end{array}$ & $\begin{array}{l}\text { "According to my opinion, taxes } \\
\text { are relatively useful and important, } \\
\text { because the government needs certain } \\
\text { income and without taxes no schools } \\
\text { or hospitals or insurance would be } \\
\text { available. A lot of positive aspects } \\
\text { would not exist." }\end{array}$ & 5 \\
\hline 1.4 & $\begin{array}{l}\text { Negative } \\
\text { associations }\end{array}$ & $\begin{array}{l}\text { Negative evalu- } \\
\text { ation of the tax } \\
\text { system or parts of } \\
\text { it is given. }\end{array}$ & $\begin{array}{l}\text { "When I hear taxes my first thought } \\
\text { is a negative one. One has to pay and } \\
\text { fees, (...). That is the first thing that } \\
\text { comes to my mind." }\end{array}$ & 5 \\
\hline
\end{tabular}

\subsection{Income Tax}

All over the world various forms of organising income tax assessment exist. One major difference is whether tax payers assess the income tax themselves or whether the revenue body assesses the tax payable (Robinson \& Slemrod, 2012, p. 243). A self-assessment system requires a more elaborate system of control and penalties, since the tax payer has more possibilities for non-compliance (James \& Alley, 2002, p. 37). A system that relies on assessments by the tax authorities entails higher administrative costs. Austria relies on tax assessed by the revenue body. In order to be able to analyse the students' personal experience with income tax, the employee assessment was chosen as one situation, were students have to get in contact with tax authorities. In Austria, even if individuals are employed only for one month a year (e.g. in an internship), income tax is still calculated on this monthly basis and as if they had worked the entire year. In order to receive the tax refund resulting from this temporary miscalculation, a form provided by the revenue body must be filled out, either on paper or online (Federal Ministry of Finance, 2016, p. 13)².

2 This regulation has been revised in 2017, and the tax credit is now returned automatically under certain conditions (Federal Ministry of Finance, 2017). 
The answers in Table 3 show that only a low number of students has already filed an employee assessment (Category 2.1 in Table 3). Still most of the students have already work experience. Most students have not yet any experience with this task (Category 2.2 in Table 3). One reason is that their parents handle this task for them as shown in the example quote in Category 2.2 in the table below. The quote strongly suggests that the student does not take responsibility for tax-related issues, despite the fact that the student attends a business college. Still, some students say that they were going to file an employee assessment in the future (2.3 in Table 3). There are, however, many insecurities on why this is done. Only four students offer an, not always correct, explanation. These answers include working only for one month (see example quote Category 2.4 in Table 3), not having a regular income and having paid too much taxes. They can be seen as correct conceptions, although not detailed ones. A misconception is the answer that being a student brings tax advantages. This misconception can be explained by the fact that the students do not see themselves as taxpayers but rather as students, who do not yet participate in the real economy (Cechovsky, 2018b) ${ }^{3}$.

Table 3: Personal Experience With Employee Assessment (Cechovsky, 2018b, p. 475)

\begin{tabular}{|c|c|c|c|c|}
\hline Number & Categories & Explanation & Example quote & Answers \\
\hline 2.1 & Filed & $\begin{array}{l}\text { Students mention that } \\
\text { they conduct an employee } \\
\text { assessment themselves. }\end{array}$ & $\begin{array}{l}\text { "I got a form from the tax office, } \\
\text { completed and returned it." }\end{array}$ & 5 \\
\hline 2.2 & Not filed & $\begin{array}{l}\text { Students mention that they } \\
\text { did not conduct an employee } \\
\text { assessment themselves. }\end{array}$ & $\begin{array}{l}\text { "I did not do it but my mum did } \\
\text { it." }\end{array}$ & 13 \\
\hline 2.3 & Plans to file & $\begin{array}{l}\text { Students have not yet } \\
\text { conducted an employee } \\
\text { assessment but have specific } \\
\text { plans of doing it in the near } \\
\text { future. }\end{array}$ & $\begin{array}{l}\text { "No, I will do it this year. So, I will } \\
\text { do it this January. I did not know } \\
\text { that this can be done for a sum- } \\
\text { mer job. Our accounting teacher } \\
\text { told us. And she said that one can } \\
\text { do it for the previous year too. } \\
\text { And so I will do it in January or } \\
\text { February." }\end{array}$ & 4 \\
\hline 2.4 & Reasons & $\begin{array}{l}\text { Students offer an explanati- } \\
\text { on why one gets money back } \\
\text { when doing an employee as- } \\
\text { sessment. }\end{array}$ & $\begin{array}{l}\text { "Well, because I worked for this } \\
\text { one month only. Because I am } \\
\text { not employed regularly and so- } \\
\text { mething with the marginal ear- } \\
\text { nings threshold, no marginal } \\
\text { earnings threshold it is not, but } \\
\text { because it is for one month only." }\end{array}$ & 4 \\
\hline
\end{tabular}

3 Further aspects concerning students' understanding of the tax system from a public finance perspective can be found in Cechovsky (2018b). 


\subsection{Value Added Tax}

According to the European Commission (2017b), almost all EU member states apply a standard value added tax rate and one or two reduced value added tax rates. Standard value added tax rates range from $17 \%$ in Luxembourg to $25 \%$ in Denmark, Croatia and Sweden. Within the European Union, reduced value added tax rates are limited to certain categories of goods and services: Foodstuffs, supply of water, pharmaceutical products, certain medical equipment and aids, transport of passengers, books, newspapers, periodicals, admission to cultural services and amusement parks, TV, services by artists, writers and composers, social housing, renovation, cleaning in private households, agricultural input, hotel accommodation, restaurants and catering. The decision to change value added tax rates for these categories is made in the member states.

Table 4 gives an overview of the students' conceptions and misconceptions of the value added tax. The first two categories focus on the number of correct answers concerning value added tax rates, whereas Category 3.3 and 3.4 relate to the explanation why different rates exist.

All students are familiar with the term value added tax and are aware that this is a tax that has to be paid when purchasing goods or services. Also, many students associate the term with the deductible input tax (in German Vorsteuer), which is part of the accounting curriculum in business colleges (Bundesministerium für Bildung, 2014). However, they are not able to explain why companies are eligible to retain the input tax.

Most students name examples of goods and their value added tax rates. Categories 3.1 and 3.2 in Table 4 show all examples and whether they are correct or not. Most frequently mentioned are the categories of food, beverages and books, probably because of personal experience from purchases with pocket money. Nineteen examples are associated with the correct value added tax rate. The example quote in Category 3.1 shows that the student has an extensive knowledge of the altered tax rates as introduced with a recent amendment to tax legislation in Austria. This student only mentions one incorrect rate, the one for bus tickets. This misconception stems from the fact that the rate of passenger transport with planes is taxed with $13 \%$. Altogether, eleven rates are given incorrectly. A common misconception is that the reduced rate of $10 \%$ value added tax is charged for beverages as shown in the example quote in Category 3.2. This misconception can be explained by the students thinking that food and beverages are taxed the same. Another misconception concerning tax rate is that there is a value added tax rate of $19 \%$ in Austria. In Austria, however, this rate exists just in two areas which are under German custom regulation. Therefore, this misconception can be explained by confusing German and Austrian tax regulations.

Around half of the students can give a suitable reason for different tax rates (Category 3.3 in Table 4). They reason that a lower rate is levied on food since everyone needs it and it should be affordable for everyone, as the quote in Category 3.3 for example shows. 
About half of the students are not able to give a reason for a distinction (Category 3.4 in Table 4). A misconception is shown in the example quote in Category 3.4, since reduced value tax rates are not connected with the price of a product but should ensure the affordability of necessary goods. An explanation for the confusion of the value added tax rates and the missing ability to explain the existence of different rates is that they are learned as factual knowledge with no further explanation of why the difference exists.

Table 4: Value Added Tax

\begin{tabular}{|c|c|c|c|c|}
\hline Number & Categories & Explanation & Example quote & Answers \\
\hline 3.1 & $\begin{array}{l}\text { Value added } \\
\text { tax rates: } \\
\text { Correct }\end{array}$ & $\begin{array}{l}\text { Correct examples } \\
\text { of value-added } \\
\text { tax rates. }\end{array}$ & $\begin{array}{l}\text { "They have now, increased for example on dog } \\
\text { food, this is now } 13 \% \text {, books are now (.) I am } \\
\text { not sure } 10 \text { or } 13 \% \text {, food is } 10 \% \text {, drinks are } 20 \% \text {, } \\
\text { except milk, I think are } 10 \% \text {. Err bus tickets or } \\
\text { something like that is increased to } 13 \% \text {, tickets } \\
\text { for a football match that is } 13 \% . "\end{array}$ & 19 \\
\hline 3.2 & $\begin{array}{l}\text { Value added } \\
\text { tax rates: } \\
\text { Incorrect }\end{array}$ & $\begin{array}{l}\text { Incorrect examp- } \\
\text { les of value-added } \\
\text { tax rates. }\end{array}$ & $\begin{array}{l}\text { "So I do not really know it. But I suspect that be- } \\
\text { verages are } 10 \% \text {, are they? I think so. Beverages } \\
\text { should be affordable for everyone." }\end{array}$ & 11 \\
\hline 3.3 & $\begin{array}{l}\text { Different } \\
\text { rates: } \\
\text { Essential } \\
\text { goods }\end{array}$ & $\begin{array}{l}\text { Explanation for } \\
\text { differences in } \\
\text { tax rates is that } \\
\text { essential goods } \\
\text { are made less } \\
\text { expensive. }\end{array}$ & $\begin{array}{l}\text { "I think, that they do not want to charge high } \\
\text { taxes on food and beverages, since those are } \\
\text { everyday goods that we need and otherwise the } \\
\text { goods would be more expensive, this would not } \\
\text { be good. Then we could not afford it anymore." }\end{array}$ & 10 \\
\hline 3.4 & $\begin{array}{l}\text { Different } \\
\text { rates: No } \\
\text { explanation }\end{array}$ & $\begin{array}{l}\text { Correct examples } \\
\text { of value-added } \\
\text { tax rates. }\end{array}$ & $\begin{array}{l}\text { "Why is it like that? Good question! I don't } \\
\text { know. I know that the rate for cinema was in- } \\
\text { creased recently. I know that, this seems a litt- } \\
\text { le bit weird to me. But why are there different } \\
\text { rates? Maybe because the goods have different } \\
\text { prices? I don't know." }\end{array}$ & 11 \\
\hline
\end{tabular}

\subsection{Tax Reform in Austria}

A tax reform presents one approach to increase the efficiency of a tax system. This approach, however, has to be tailored to the economic and legal situation of the country (European Commission, 2016b, p. 17). A trend starting in 2014/15 in the European Union shows a shift from taxing labour to taxing capital. Tax reforms intending to cut labour tax are a method to increase employment. In order to finance an income tax reform, there has also been a trend towards an increase of taxes on consumption and recurrent property tax since 2010. Apart from Austria, also Croatia, Portugal and Finland recently put a reform into effect to decrease personal income tax (European Commission, 2017c). Table 5 illustrates the students' concep- 
tions and misconceptions of a recently introduced tax reform in Austria. It shows that more than half of the students remember some details of the reform.

The 2015/16 tax reform in Austria comprises amendments to twenty different laws (Bundesministerium für Finanzen, 2015). The most important alterations include changes in the income tax rates, various changes concerning deductions and allowances, changes concerning social security insurance, changes in the rates of the capital gains tax, changes in the property transfer tax and changes in the value added tax rates (Bundesministerium für Digitalisierung und Wirtschaftsstandort, 2015).

Four students do not even know that a tax reform had been passed (Category $4.1 \mathrm{in} \mathrm{Ta-}$ ble 5). Four more students remember that they heard about it but cannot recall any details as the quote in Category 4.2 illustrates. Not remembering the reform or not recalling details about it can be explained by the perceived irrelevance of tax-related issues for students.

More than half of the students had heard about and remember some details of the tax reform (Categories 4.3, 4.4 and 4.5 in Table 5). Most statements refer to the changes in the value added tax and the income tax. As regards the value added tax (Category 4.3 in Table 5), many students remember a change in the tax rate in general. However, only one student is able to mention various examples. Another wrongly remembers an increase in the tax rate for cigarettes. Major changes in income tax are summarised by a student with the sample quote in Category 4.4. This conception is consistent with scientific explanations.

There are also misconceptions about the new income tax legislation. One student wrongly remembers an increase in income tax: "We talked about it [the reform] a little bit at home because the income tax was increased, wasn't it? But none of us was directly affected by it". This misconception can stem from solely remembering that the situation for people who earn a high income have to pay a higher share of income tax, but not recalling that the situation improved for lower income people.

Another student mentions the change in the property transfer tax because the student's family is affected by it: "Yes, my family has been affected by it, for example the inheritance tax was increased - at least I think it was so. And the property transfer tax". This again supports the explanation that students do remember details of a reform only if they are of immediate importance for them or their family. Furthermore, the student wrongly remembers a change in the inheritance tax which does not exist in Austria. This misconception can stem from a confusion with the property transfer tax which is also levied when getting a property free of charge, which is the case when a property is inherited. 
Table 5: Tax Reform in Austria

\begin{tabular}{|c|c|c|c|c|}
\hline Number & Categories & Explanation & Example quote & Answers \\
\hline 4.1 & $\begin{array}{l}\text { Not heard } \\
\text { about }\end{array}$ & $\begin{array}{l}\text { Student has not } \\
\text { heard or read about } \\
\text { the tax reform. }\end{array}$ & $\begin{array}{l}\text { "No, tax reform, I do not know anything } \\
\text { about this." }\end{array}$ & 4 \\
\hline 4.2 & $\begin{array}{l}\text { Heard but no } \\
\text { memory on } \\
\text { details }\end{array}$ & $\begin{array}{l}\text { Student has heard or } \\
\text { read about the tax } \\
\text { reform but does not } \\
\text { recall details. }\end{array}$ & $\begin{array}{l}\text { "Yes, noticed. Err I have heard of the } \\
\text { tax reform. We shortly covered it in the } \\
\text { subject accounting. But I do not remem- } \\
\text { ber anymore what happened. But I have } \\
\text { heard of it." }\end{array}$ & 4 \\
\hline 4.3 & $\begin{array}{l}\text { Value added } \\
\text { tax }\end{array}$ & $\begin{array}{l}\text { Conceptions and } \\
\text { misconceptions } \\
\text { concerning changes } \\
\text { relating to the value- } \\
\text { added tax. }\end{array}$ & $\begin{array}{l}\text { "I only know that the VAT rates on books } \\
\text { have been changed." }\end{array}$ & 6 \\
\hline 4.4 & Income tax & $\begin{array}{l}\text { Conceptions and } \\
\text { misconceptions } \\
\text { concerning chan- } \\
\text { ges relating to the } \\
\text { income tax. }\end{array}$ & $\begin{array}{l}\text { "I only know, that there have been three } \\
\text { rates for income tax and now there are } \\
\text { five and this is fairer now and most peop- } \\
\text { le have more money remaining after tax. } \\
\text { Except maybe the very rich ones, because } \\
\text { they fall into the highest tax category } \\
\text { (Laughs)." }\end{array}$ & 6 \\
\hline 4.5 & $\begin{array}{l}\text { Property } \\
\text { transfer tax }\end{array}$ & $\begin{array}{l}\text { Conceptions and } \\
\text { misconceptions } \\
\text { concerning changes } \\
\text { relating to the pro- } \\
\text { perty transfer tax. }\end{array}$ & $\begin{array}{l}\text { "Yes, my family has been affected by it, for } \\
\text { example the inheritance tax was increa- } \\
\text { sed - at least I think it was so. And the } \\
\text { property transfer tax". }\end{array}$ & 1 \\
\hline
\end{tabular}

\section{Summary and Discussion}

There are several limitations to this study. First of all, the target group of Austrian students from business colleges is very specific. These students do have a prior knowledge in business administration and accounting topics. Therefore, one has to be cautious in interpreting and generalising any results. Moreover, some results are specific to regulations in Austria. Therefore, further studies should focus on different countries and other target groups. Furthermore, no explicit analysis according to sampling categories was conducted due to the small sample. This could be considered as an interesting research question for further studies as well.

Students from business colleges in Austria between the ages of 17 and 18 are a relevant target group for exploring conceptions and misconceptions concerning taxes. They already have some money at their disposal and, therefore, act as consumers and pay value added tax. In addition, they earn money for the first time by doing internships or working part-time. Also, they are allowed to take part in the democratic process of elections which enables them to influence tax-related policies. Some of them even start thinking of business ideas and 
starting a company, since the curriculum of this school is targeted towards entrepreneurship education (Bundesministerium für Bildung, 2014).

The first associations indicate that a misconception concerning fees and taxes exist. This misconception has found to be a common one by a quantitative study conducted among 688 students from business colleges at the same age (17 to 18) in Austria (Cechovsky, 2018a, p. 148). This questionnaire study found that one third of the students did not know that they are not entitled to a specific service in return to tax payments. When looking at this misconception from a cognitive psychology point of view (Marton, 2005; Busom et al., 2017), the bias might stem from the interchangeable use of the terms fees and taxes in everyday language. Teachers should be aware of this common misconception. This can be classified as pedagogical content knowledge according to Shulman (1986), which should be addressed in teacher trainings for inexperienced teachers. The new teachers should be taught to explicitly discuss common misconceptions in the classroom. The curriculum shows that no explicit competences on the basic principles of the tax system are taught. These basic competences could be integrated in the first year in the subject business administration in order to build a basic economic understanding for further tax-related content. Furthermore, the first associations include positive as well as negative evaluations of taxes, which can be related to tax compliance as found out by Hofmann et al. (2008). It would be of interest to further study this relationship.

The interview results on the income tax show that students are often not aware of tax-related issues on an individual level. This becomes visible since many students have not yet filed an employee assessment. These findings are in line with other studies in this field (Furnham, 2005; Furnham \& Rawles, 2004). Not filing an employee assessment in the case of an internship, however, leads to a loss of money for the individual. Most of the students have already worked, still they do not perceive themselves as taxpayers. From a phenomenographic point of view (Marton, 2005) it is of interest to look at the different explanations for getting a tax credit when filing an employee assessment and how these could be addressed by teachers in class in order to change them. A further possible starting point could be the structure of the curriculum. On a curricular level, in the subject accounting the content very much focuses on business-related issues. In order to foster an understanding on the individual level, the tax-related issues for the private individual should be integrated earlier in the curriculum and can build the basis for the perspective of the company owner. This would help to connect tax-related issues to the students' life situations. Furthermore, teacher training should convey that also for practical tasks it is not sufficient to focus on "how it is done" but also the question "why it is done" is of importance.

Value added tax is a tax that students are usually familiar with. However, students lack a deeper understanding of the reasons for different tax rates. This makes it harder for them to remember the goods and services that differ from the regular value added tax rate. Yet, 
instruction should not only focus on factual knowledge concerning the different value added tax-rates but also convey background information on the reasons for and effects of different value added tax rates, since half of the students were not able to provide a reason for the difference. As pointed out in the theoretical section the uncovered misconception, for example that food and beverages are taxed the same, should be actively addressed in a classroom setting (Marton, 2005; Busom et al., 2017). Thus, teachers could for example discuss the different value added tax rates by focusing on the reasons why they exist, which makes it easier to understand and remember the main differences in rates.

Tax reforms frequently occur in all countries of the European Union (European Commission, 2016b). The results of the interviews on a recent major tax reform in Austria show that changes in tax regulations lead to confusion. Furthermore, the tax reform was not even recognized by all students and only some remember certain details about it. This leads to the conclusion that students are only interested in tax-related issues if they or their family is directly concerned with it. Therefore, tax reforms as well as their impact for the private person and businesses should be part of the instruction in the subject accounting in order to make sure that the important changes are recognised and understood by the students. Tax reforms from a governmental view can be integrated in the subject economics.

To conclude, it needs to be stressed that tax education is an important part of economic education that should be part of a European civic education. Furthermore, tax education should next to information important for personal taxation issues such as filing an income tax return, offer information on a societal level as the definition on tax literacy suggests. Knowledge of the tax system as a whole and being aware of the need for public goods in a country, as well as the effects on a society, can contribute to the understanding why taxes and tax compliance are vital.

\section{References}

Ajzen, I. (1991). The theory of planned behavior. Organizational Behavior and Human Decision Processes, 50(2), 179-211. https://dx.doi.org/10.1016/0749-5978(91)90020-T

American Psychological Association (2017). Ethical principles of psychologists and code of conduct. APA. https://www.apa.org/ethics/code/?item $=11 \# 802$

Aprea, C. (2015). Secondary school students' informal conceptions of complex economic phenomena. International Journal of Educational Research, 69, 12-22. https://doi.org/10.1016/j.ijer.2014.09.002

Aprea, C., \& Sappa, V. (2014). Variations of young Germans' informal conceptions of financial and economic crises phenomena. JSSE-Journal of Social Science Education, 13(3), 57-67. https://doi.org/10.4119/jsse-710

Atkinson, A., \& Messy, F. A. (2012). Measuring financial literacy: Results of the OECD / International network on financial education (INFE) pilot study. OECD Working Papers on Finance, Insurance and Private Pensions, No. 15, OECD Publishing. https://doi.org/10.1787/5k9csfs90fr4-en 
Beck, K. (1989). „Ökonomische Bildung“ - Zur Anatomie eines wirtschaftspädagogischen Begriffs ["Economic Education" - The structure of a business educational term]. Zeitschrift für Berufs-und Wirtschaftspädagogik, 85(7), 579-596.

Bhushan, P., \& Medury, Y. (2013). Determining tax literacy of salaried individuals-an empirical analysis. IOSR Journal of Business and Management, 10(6), 76-80.

Birke, F., \& Seeber, G. (2011). Heterogene Schülerkonzepte für ökonomische Phänomene: Ihre Erfassung und Konsequenzen für den Unterricht [Students' heterogeneous concepts of economic phenomena: How to ascertain these and consequences in the classroom]. JSSE-Journal of Social Science Education, 10(2), 56-66. https://dx.doi.org/10.2390/jsse-v10-i2-1164

Bundesministerium für Bildung (2014). Lehrplan der Handelsakademie [Curriculum of business colleges]. HAK. https://www.hak.cc/files/syllabus/Lehrplan_HAK_2014.pdf

Bundesministerium für Digitalisierung und Wirtschaftsstandort (2015). Steuerreform 2015/2016 [Tax Reform 2015/2016]. Oesterreich.gv.at. https://www.help.gv.at/Portal.Node/hlpd/public/content/340/Seite.34060831.html

Bundesministerium für Finanzen (2015). Steuerreformgesetz 2015/16 [Tax reform regulations 2015/16]. Bundesministerium Finanzen. https://www.bmf.gv.at/rechtsnews/steuern-rechtsnews/ archiv-gesetze-und-verordnungen/2015/steuerreformgesetz-2015-16.html

Busom, I., Lopez-Mayan, C., \& Panadés, J. (2017). Students' persistent preconceptions and learning economic principles. The Journal of Economic Education, 48(2), 74-92. https://doi.org/10.1080/00 220485.2017.1285735

Cechovsky, N. (2018a). Tax literacy of Austrian students: A mixed methods study of tax knowledge and tax compliance among students from business colleges (Doctoral dissertation, Vienna University of Economics and Business, Austria).

Cechovsky, N. (2018b). Students' fiscal literacy: An explorative study of their understanding of the tax system. Empirische Pädagogik, 32(3/4), 460-479.

Chardon, T., de Zwaan, L., Palm, C., \& Liu, Y. (2016). University students and tax literacy: Opportunities and lessons for tax teaching. Journal of The Australasian Tax Teachers Association, 11(1), $85-102$.

Cvrlje, D. (2015). Tax literacy as an instrument of combating and overcoming tax system complexity, low tax morale and tax non-compliance. The Macrotheme Review, 4(3), 156-167.

Davies, P., \& Lundholm, C. (2012). Students' understanding of socio-economic phenomena: Conceptions about the free provision of goods and services. Journal of Economic Psychology, 33(1), 79-89. https://doi.org/10.1016/j.joep.2011.08.003

Djawadi, B., \& Fahr, R. (2013). The impact of tax knowledge and budget spending influence on tax compliance. Discussion Paper Series. Forschungsinstitut zur Zukunft der Arbeit, No. 7255.

Eriksen, K., \& Fallan, L. (1996). Tax knowledge and attitudes towards taxation; A report on a quasi-experiment. Journal of Economic Psychology, 17(3), 387-402. https://doi.org/10.1016/01674870(96)00015-3

Eryilmaz, A. (2002). Effects of conceptual assignments and conceptual change discussions on students' misconceptions and achievement regarding force and motion. Journal of Research in Science Teaching, 39(10), 1001-1015. https://doi.org/10.1002/tea.10054

European Commission (2016a). Proposal for a council directive amending directive (EU) 2016/1164 as regards hybrid mismatches with third countries. Strasbourg. EUR-Lex. https://eur-lex.europa.eu/ legal-content/EN/TXT/?uri=COM:2016:687:FIN 
European Commission (2016b). Tax policies in the European Union. 2016 survey. European Commission. https:/ec.europa.eu/taxation_customs/business/company-tax/tax-good-governance/ european-semester/tax-policies-european-union-survey_en

European Commission (2017a). Commission welcomes adoption of new rules to block tax avoidance [press release]. European Commission. https://europa.eu/rapid/press-release_IP-17-1433_en.htm

European Commission (2017b). VAT rates applied in the member states of the European Union. Situation at 1st January 2017. European Commission. https:/ec.europa.eu/taxation_customs/sites/ taxation/files/resources/documents/taxation/vat/how_vat_works/rates/vat_rates_en.pdf

European Commission (2017c). Tax policies in the European Union. 2017 survey. European Commission. https://ec.europa.eu/taxation_customs/sites/taxation/files/tax_policies_survey_2017.pdf

Eurostat (2016). Tax revenue statistics. Eurostat. https:/ec.europa.eu/eurostat/statistics-explained/index.php/Tax_revenue_statistics

Federal Ministry of Finance (2016). The tax book 2017. Advice on the tax assessment for employees in 2016. Bundesministerium Finanzen. https://www.bmf.gv.at/dam/jcr:7b322448-2921-4aa7-a86b9c51d37307f6/BMF-Tax_Book_2017.pdf

Federal Ministry of Finance (2017). The tax book 2018. Tips for employee tax assessment 2017. Bundesministerium Finanzen. https://www.bmf.gv.at/dam/jcr:ed1bf62e-8a0d-4da3-9b59-2ffe9e93b08d/ The_Tax_Book_2018_-_Web.pdf

Furnham, A. (2005). Understanding the meaning of tax: Young peoples' knowledge of the principles of taxation. The Journal of Socio-economics, 34(5), 703-713. https://doi.org/10.1016/j.socec.2005.07.014

Furnham, A., \& Rawles, R. (2004). Young people's ignorance about the topic of taxation. Citizenship, Social and Economics Education, 6(1), 12-23. https://doi.org/10.2304/csee.2004.6.1.12

Gangl, K., Torgler, B., Kirchler, E., \& Hofmann, E. (2014). Effects of supervision on tax compliance: Evidence from a field experiment in Austria. Economics Letters, 123(3), 378-382. https://doi. org/10.1016/j.econlet.2014.03.027

Gurel, D. K., Eryilmaz, A., \& McDermott, L. C. (2015). A review and comparison of diagnostic instruments to identify students' misconceptions in science. Eurasia Journal of Mathematics, Science \& Technology Education, 11(5), 989-1008. https://doi.org/10.12973/eurasia.2015.1369a

Hofmann, E., Hölzl, E., \& Kirchler, E. (2008). Preconditions of voluntary tax compliance: Knowledge and evaluation of taxation, norms, fairness, and motivation to cooperate. Zeitschrift für Psychologie, 216(4), 209-217. https://doi.org/10.1027/0044-3409.216.4.209

Holtsch, D., \& Eberle, F. (2016). Learners' economic competence in Switzerland: Conceptual foundations and considerations for measurement. In E. Wuttke, J. Seifried \& S. Schumann (Eds.), Economic competence and financial literacy of young adults. Status and challenges (pp. 101-119). Barbara Budrich.

Ignell, C., Davies, P., \& Lundholm, C. (2017). Understanding 'price' and the environment: Exploring upper secondary students' conceptual development. JSSE-Journal of Social Science Education, 16(1), 68-80. https://doi.org/10.4119/jsse-822

James, S., \& Alley, C. (2002). Tax compliance, self-assessment and tax administration. Journal of Finance and Management in Public Services, 2(2), 27-42.

Kamleitner, B., Korunka, C., \& Kirchler, E. (2012). Tax compliance of small business owners: A review. International Journal of Entrepreneurial Behavior \& Research, 18(3), 330-351. https://doi. org/10.1108/13552551211227710 
Kirchler, E., Hölzl, E., \& Wahl, I. (2008). Enforced versus voluntary tax compliance: The 'Slippery slope' framework. Journal of Economic Psychology, 29(2), 210-225. https://doi.org/10.1016/j. joep.2007.05.004

Kirchler, E., Niemirowski, A., \& Wearing, A. (2006). Shared subjective views, intent to cooperate and tax compliance: Similarities between Australian taxpayers and tax officers. Journal of Economic Psychology, 27(4), 502-517. https://doi.org/10.1016/j.joep.2006.01.005

Lamnek, S. (2010). Qualitative Sozialforschung [Qualitative research in social science] (5th ed.). Beltz.

Latiff, A. R. A., Noordin, B. A. A., Omar, M. R. C., \& Harjito, D. A. (2005). Tax literacy rate among taxpayers: Evidence from Malaysia. Jurnal Akuntansi dan Auditing Indonesia, 9(1), 1-11.

Markowitsch, J., \& Hefler, G. (2018). Staying in the Loop: Formal Feedback Mechanisms Connecting Vocational Training to the World of Work in Europe. International Journal for Research in Vocational Education and Training, 5(4), 285-306. https://doi.org/10.13152/IJRVET.5.4.3

Marton, F. (2005). Phenomenography: A research approach to investigating different understandings of reality. In R. R. Sherman \& R. B. Webb (Eds.), Qualitative research in education: Focus and methods (pp. 151-171). Routledge Falmer.

Mayring, P. (2015). Qualitative Inhaltsanalyse. Grundlagen und Techniken [Qualitative content analysis. Basics and methods] (12th ed.). Beltz.

Nakhleh, M. B. (1992). Why some students don't learn chemistry: Chemical misconceptions. Journal of Chemical Education, 69(3), 191-196. https://doi.org/10.1021/ed069p191

Organisation for Economic Co-Operation and Development, \& The International and Ibero-American Foundation for Administration and Public Policies (2015). Building tax culture, compliance and citizenship: A global source book on taxpayer education. https://dx.doi.org/10.1787/9789264205154en

Oladipupo, A. O., \& Obazee, U. (2016). Tax knowledge, penalties and tax compliance in small and medium scale enterprises in Nigeria. iBusiness, 8, 1-9. https://dx.doi.org/10.4236/ib.2016.81001

Palil, M. R., Akir, M. R., \& Ahmad, W. F. B. W. (2013). The perception of tax payers on tax knowledge and tax education with level of tax compliance: A study the influences of religiosity. ASEAN Journal of Economics, Management and Accounting, 1(1), 118-129.

Robinson, L., \& Slemrod, J. (2012). Understanding multidimensional tax systems. International Tax and Public Finance, 19, 237-267. https://dx.doi.org/10.1007/s10797-011-9183-y

Schumann, S., Oepke, M., \& Eberle, F. (2011). Über welche ökonomischen Kompetenzen verfügen Maturandinnen und Maturanden? Hintergrund, Fragestellungen, Design und Methode des Schweizer Forschungsprojekts OEKOMA im Überblick [What economic competences do matura-students possess? Background, research question, design and method of the Swiss research project OEKOMA - An overview]. In U. Faßhauer, J. Aff, B. Fürstenau \& E. Wuttke (Eds.), Lehr-Lernforschung und Professionalisierung. Perspektiven der Berufsbildungsforschung [Research on teaching and learning and professionalisation. Perspectives of educational research] (pp. 51-63). Farmington Hills.

Shulman, L. S. (1986). Those who understand: Knowledge growth in teaching. Educational Researcher, 15(2), 4-14. https://doi.org/10.3102/0013189X015002004

Smith III, J. P., Disessa, A. A., \& Roschelle, J. (1994). Misconceptions reconceived: A constructivist analysis of knowledge in transition. The Journal of the Learning Sciences, 3(2), 115-163. https://doi. org/10.1207/s15327809jls0302_1 
Vella, J. (2015). Corporate tax practices and aggressive tax planning in the EU. In-depth analysis for the ECON committee. European Parliament. http://www.europarl.europa.eu/RegData/etudes/ IDAN/2015/563446/IPOL_IDA(2015)563446_EN.pdf

Witzel, A., \& Reiter, H. (2012). The problem-centred interview. Sage.

Wong, R. M., \& Lo, W. A. (2015). Can education improve tax compliance? Evidence from different forms of tax education. HKIBS Working Paper Series 074-1415. Hong Kong Institute of Business Studies. Core. https://core.ac.uk/download/pdf/49307568.pdf

Yates, T. B., \& Marek, E. A. (2014). Teachers teaching misconceptions: A study of factors contributing to high school biology students' acquisition of biological evolution-related misconceptions. Evolution: Education and Outreach, 7(7), 1-18. https://doi.org/10.1186/s12052-014-0007-2

\section{Biographical Note}

Dr Nora Cechovsky is a researcher at the Institute of Business Education at the Vienna University of Economics and Business in Vienna, Austria. Her research focuses on tax literacy as a part of a sound economic literacy. Furthermore, she has done research on teaching methods in soft skills development and in the field of teacher education. 